\title{
Apuntes
}

\section{Ferrocarriles. Sedes web}

Lorena Ortiz Lozano

Centro de Documentación del IAPH

\section{Canadian Railroad Historical Association Web: www.exporail.org \\ Idiomas: Inglés y francés}

Asociación sin ánimo de lucro cuyo fin es la conservación y difusión del patrimonio ferroviario en Canadá, así como la adquisición de objetos y documentos concernientes al desarrollo histórico y tecnológico del ferrocarril canadiense.

\section{Centro de Estudios Históricos del Ferrocarril Español Web: www.cehfe.es Idioma: Español}

Institución de carácter privado dedicada a promover la investigación con respecto a la evolución de los ferrocarriles españoles de ancho normal. Contiene, además de enlaces, servicios y actuaciones, un pormenorizado catálogo de fondos documentales relacionados con el ferrocarril.

Fundación de los Ferrocarriles Españoles Web: www.ffe.es

Idiomas: Español e inglés

La Fundación de los Ferrocarriles Españoles es una entidad cultural que tiene por objetivo promover el transporte por ferrocarril mediante actividades culturales, cursos, museos, edición de la revista Vía Libre, estudios, archivo y biblioteca, entre otras acciones. Información sobre actividades, documentación, estudios, publicaciones y enlaces.

Museo del Ferrocarril

Web: www.museodelferrocarril.org

Idiomas: Español e inglés

Museo dependiente de la Fundación de los Ferrocarriles Españoles, ofrece información sobre la colección, actividades, exposiciones itinerantes y restauraciones.

Museo del Ferrocarril Vilanova i la Geltrú

Web: www.ffe.es/vilanova/index.html

Idiomas: Español, catalán e inglés

Museo de la Fundación de los Ferrocarriles Españoles. Incluye fotografías, información de la biblioteca, actividades didácticas y tienda.

Institute of Railways Studies and Transport History Web: www.york.ac.uk/inst/irs/

Idiomas: Inglés
Instituto de investigación de la Universidad de York (Reino Unido) destinado al estudio de la historia del transporte. Acceso a fuentes y artículos, lista de correo, además de un programa académico de posgrado. Versión para navegadores de sólo texto.

\section{National Railway Museum \\ Web: www.nrm.org.uk \\ Idiomas: Inglés}

El museo más grande de mundo dedicado al ferrocarril, situado en York (Reino Unido). La sede web ofrece información exhaustiva acerca de exposiciones, sus colecciones, programas de investigación y fondo documental, oficina de prensa, enlaces, etc.

FEDECRAIL. Fédération Européenne des Chemins de Fer Touristiques et Historique

Web: www.fedecrail.org

Idiomas: Inglés, francés y alemán

La Federación Europea de Ferrocarriles Turísticos e Históricos representa a las organizaciones nacionales de ferrocarriles turísticos e históricos ante las instituciones europeas. Entre sus actividades están la publicación de un boletín y la organización de una conferencia anual sobre patrimonio ferroviario.

FerroBase SurLeWeb

Web: gillesrudelle.free.fr/FerroBaseSurLeWeb/index.php? function= show_search_form\&table_name=FerroBase Idioma: Francés

Base bibliográfica de prensa con más de 15.000 referencias sobre ferrocarriles.

El Tren del Fin del Mundo

Web: www.trendelfindelmundo.com.ar Idioma: Español

Tren que recorre la región de Ushuaia en Argentina, su nombre le viene porque la estación de cabecera se sitúa en plena Tierra de Fuego. Ofrece información sobre la historia del ferrocarril, imágenes y proyectos actuales.

\section{Die Erlebnis-Tramway}

\section{Web: www.museumstramway.at}

Idioma: Alemán

Web del Museo del Tranvía de Mariazell (Austria). Información sobre actividades, foro, newsletter y colección. 